Marit Lindset \& Britt Karin Støen Utvær (2017). Fra fagarbeider til yrkesfaglærer: Førsteårsstudenters opplevelser av undervisning og veiledning i akademiske skriveferdigheter. Scandinavian Journal of Vocations in Development.

http://dx.doi.org/10.7577/sjvd.2007

Peer reviewed article

Fagfellevurdert artikkel

\title{
Fra fagarbeider til yrkesfaglærer: Førsteårsstudenters opplevelser av undervisning og veiledning i akademiske skriveferdigheter
}

Forfattere:

Marit Lindset \& Britt Karin Støen Utvær

Norges Teknisk - naturvitenskapelige universitet - NTNU,

Fakultet for samfunns- og utdanningsvitenskap

britt.karin.utvar@plu.ntnu.no

marit.lindset@ntnu.no

Nøkkelord: akademisk skriving, yrkesfaglærerutdanning, skrivekurs, tilbakemeldinger på oppgaver 


\section{Sammendrag}

Introduksjon: Yrkesfaglærerstudentene begynner på en utdanning der gode skriveferdigheter er en forutsetning for å klare seg gjennom utdanningen. Som lærerutdannere opplever vi at mange studenter strever med å beherske de kravene som stilles til akademisk skriving i høyere utdanning. Dette var bakgrunnen for at to lærere ved 3-årig yrkesfaglærerutdanningen i Trondheim startet en studie hvor formålet var å utforske hvordan førsteårstudentene opplevde et innføringskurs i skriving av akademiske oppgaver og ulike former for tilbakemelding på oppgaver i studiet (skriftlige, muntlige og digitale).

Teori: Studien støtter seg i hovedsak til Illeris sine perspektiver på læring.

Metode: Dataene utgjør 24 refleksjonslogger av 12 førsteårsstudenter i perioden 2014 - 2015. Analysene baserer seg på Lindseth og Norbergs fenomenologiske- hermeneutiske fremgangsmåte.

Resultat: Studien viser at studentene ser et innføringskurs i akademisk skriving som helt nødvendig og av stor betydning for utvikling av deres skriveferdigheter og for videreutvikling av oppgaver. Konkrete, skriftlige tilbakemeldinger direkte i teksten sammen med en oppsummerende tekst til slutt er en form for tilbakemelding studentene opplever som viktig og nyttig. Muntlige tilbakemeldinger virker oppklarende og motiverende. Sammen med muntlige tilbakemeldinger fremheves digitale tilbakemeldinger som svært viktig for å skape trygghet og motivasjon for å jobbe videre.

Konklusjon: Førsteårsstudenter forteller om stor usikkerhet og sårbarhet i skrivearbeidet. De opplever et skrivekurs som vesentlig for å mestre kravene som stilles til akademisk skriving i høyere utdanning og ser kvaliteter ved både skriftlige, muntlige og digitale tilbakemeldinger i arbeidet med å ferdigstille oppgaver i studiet. Skriftlige tilbakemeldinger oppleves som helt nødvendige.

Nøkkelord: akademisk skriving, yrkesfaglærerutdanning, skrivekurs, tilbakemeldinger på oppgaver 


\begin{abstract}
Introduction: Students pursuing a bachelor's degree in the Vocational Teacher Education program find that good writing skills are a prerequisite to complete their education. As educators in this program, we experience that many students struggle to master the requirements for academic writing in higher education. For this reason, two teachers from the Vocational Teacher Education bachelor's degree program in Trondheim undertook a study with the purpose of exploring how first-year students experienced an introductory course in academic writing and different forms of feedback on assignments (written, oral, and digital).

Theory: The study relies mainly on Illeris's Learning Theory.
\end{abstract}

Method: Data collection is based on 24 reflection logs of 12 first-year students during 20142015. The analysis is based on Lindseth and Norberg's phenomenological-hermeneutical method.

Result: The findings of the study show that students experience the introductory course in academic writing as absolutely necessary and of great importance for the development of their writing competence. Specifically, responses written directly in the text in addition to a summary are forms of feedback students perceive as important and helpful. Along with oral responses, digital responses are central for developing confidence and motivation to continue working.

Conclusion: First-year students express insecurity and vulnerability in regard to the writing process. They experience the writing course as essential and see aspects of written, oral, and digital guidance as important to the process of completing academic assignments in Vocational Teacher Education. Written feedback is perceived as absolutely necessary.

Keywords: academic writing, Vocational Teacher Education, course in academic writing, tutor response 


\section{Introduksjon}

Mange studenter opplever at det er vanskelig å beherske de kravene som stilles til akademisk skriving i høyere utdanning, spesielt det første studieåret. Studier viser at dette gjelder spesielt studenter i høyere utdanning som er tatt opp på grunnlag av realkompetanse (Grepperud, Rønning \& Støkken, 2006; Hoel \& Rokkones, 2012). Dette er også vår erfaring som mangeårige lærere ved 3-årig yrkesfaglærerutdanning i Trondheim.

Med utgangspunkt i fagarbeidere som ønsker å kvalifisere seg til et læreryrke, har vi gjennom flere år arbeidet med å utvikle undervisning og veiledning. Hensikten er å kvalifisere, veilede og støtte studenter i prosessen med å skrive akademiske tekster som utgjør mange oppgaver i studiet. Gjennom å utvikle vår undervisning og anvende ulike strategier for veiledning $\varnothing n s k e r$ vi å bidra til at studentene utvikler sine skriveferdigheter og opplever mestring i studiet. $\AA$ utvikle skriveferdigheter i første studieår vil danne et godt grunnlag for skriveprosesser i de følgende studieårene. Mye av vurderingene i studiet tar utgangspunkt i skriftlig arbeid. $\AA$ mestre studiet er derfor avhengig av hvorvidt studentene lykkes i det skriftlige arbeidet (Hoel \& Rokkones, 2012).

Som en følge av Kunnskapsløftet har grunnleggende ferdigheter i alle fag fått en sentral plass både i grunnopplæringen og i lærerutdanningen (Kunnskapsdepartementet, 2013; Utdanningsdirektoratet, 2006). Forskrift til rammeplan for treårig yrkesfaglærerutdanning fra 2013 understreker at yrkesfaglærere gjennom studiet skal arbeide systematisk med disse ferdighetene (Kunnskapsdepartementet, 2013). Ettersom grunnleggende ferdigheter i skriving nå er lagt til alle fag i skolen må både lærere og lærerutdannere sette seg bedre inn i mange sider ved skriving enn tidligere. Mens skriving og skriveopplæring tidligere var norsklæreres sitt domene, angår dette nå alle lærere uavhengig av fag (Hoel, 2008). Med dette som utgangspunkt startet to lærere ved yrkesfaglærerutdanning ved NTNU høsten 2014 et prosjekt med målsetting om å utvikle studentenes kompetanse i å skrive oppgaver innenfor universitet og høyskoler der akademiske tekster er rådende. Med akademiske skriving menes at man uttrykker seg i et eksakt og objektivt språk, videre at teksten har en klar struktur og logisk oppbygning. Kritisk refleksjon, aktivt bruk av referanser og korrekt kildehenvisninger er en 
selvfølge (Busch, 2013). Den vanligste strukturen på akademiske tekster er IMRoD ${ }^{1}$ (Hoel, 2008).

Prosjektet tar utgangspunkt i førsteårsstudentene. Studenter opplever tidlig i utdanningsløpet at kravene som stilles til akademisk skriving kan være vanskelig å fylle, samtidig som første studieåret danner grunnlaget for de to neste årene i lærerutdanningen. Å komme godt i gang med skriving tidlig i studiet anser vi som viktig, ikke minst fordi vurderingsordningen i de fleste emner det første studieåret er mappeeksamen som inneholder oppgaver med IMRoDstruktur.

For å styrke studentenes kompetanse og mestringsopplevelse i arbeidet med disse oppgavene har vi iverksatt to tiltak. Vi har utviklet et todagers kurs med innføring i akademisk skriving. Dette kurset blir tilbudt på den første samlingen i studiet. Det andre tiltaket er iverksetting av flere former for tilbakemeldinger på de ulike oppgavene. Helt siden studiet ble etablert i 2007 har studentene fått skriftlige tilbakemeldinger på oppgaver. I dette prosjektet har vi i tillegg innført muntlige tilbakemeldinger på oppgaver en gang per semester samt digitale tilbakemeldinger til en del studenter. Digital tilbakemelding innebærer muntlig formidling via lyd- og bilde. Studier viser at veiledning og tilbakemelding har betydning for studenters opplevelser av mestring, gjennomføring og karakterer (Firing, Klomsten \& Moen, 2013). Det er derimot relativt lite forskning på hvordan lærerinstitusjonene driver opplæring i akademisk skriving, og hvordan dette forstås og oppleves av studentene (Handal, Lycke \& Lauvås, 2013).

Hensikten med denne artikkelen er å gjøre rede for hvordan innføringskurset og de ulike formene for tilbakemeldinger oppleves av studentene. Med dette som utgangspunkt belyses følgende problemsstilling: Hvordan opplever førsteårsstudenter undervisning og veiledning $i$ prosessen med å skrive akademiske oppgaver? Våre forskningsspørsmål er: a) Hvordan opplever studentene innføringskurset i oppgaveskriving? b) Hvordan opplever studentene skriftlige, muntlige og digitale tilbakemeldinger på oppgaver $i$ studiet?

I artikkelen bruker vi både begrepene veiledning og tilbakemelding. Veiledning er ifølge Handal og Lauvås (2013) en læringsprosess som foregår mellom student og veileder og er,

1IMRoD er en norsk betegnelse for IMRAD som står for Introdution, Material/Method, Results og Discussion. 
slik vi ser det, et bredere begrep enn tilbakemelding. I artikkelen bruker vi tilbakemelding når vi omtaler lærernes kommentarer gitt på studentenes oppgaver, veiledning bruker vi når dialog mellom lærer og student også inngår.

\section{Teori}

Å mestre de kravene som stilles til å skrive akademiske oppgaver i lærerstudiet forutsetter læring og utvikling. Studentenes lærings- og utviklingsarbeid blir i denne studien knyttet til Illeris sine perspektiver på læring. Som hjelp og støtte i prosessen med å skrive oppgaver er lærernes veiledning sentral. I vårt arbeid med veiledning og tilbakemelding på studentenes oppgaver har vi valgt å støtte oss til Tveiten, Hoel, Handal, Lycke og Lauvås og Gamlem.

\section{Læring}

Illeris ser på læring som et komplekst og mangesidig begrep og beskriver læring som «enhver prosess som hos levende organismer fører til en varig kapasitetsendring som ikke bare skyldes glemsel, biologisk modning eller aldring» (2012, s. 16). Gjennom mange års arbeid har han utviklet to modeller hvor han søker å favne denne kompleksiteten. I modellene synliggjøres det han benevner som læringens to prosesser og tre dimensjoner. De to prosessene omtaler han som tilegnelsesprosessen og samspillsprosessen (Figur 1). Illeris hevder at begge må være aktive for at vi skal lære. Tilegnelsesprosessen er en indre mental tilegnelse og bearbeidelse av de nye impulsene, og samspillsprosessen en prosess basert på samspillet mellom individet og dets omgivelser Tilegnelses- og samspillsprosessen skjer innenfor rammene av en sosial og samfunnsmessig kontekst (Figur 2).

De tre dimensjonene i læring benevner Illeris (2012) som innhold, drivkraft og samspill (Figur 2). Innholdsdimensjonen dreier seg om kunnskap, forståelse og ferdigheter. Gjennom den prøver vi generelt å skape mening og mestring og derigjennom styrker vi vår funksjonalitet. Drivkraftdimensjonen omfatter motivasjon, følelser og vilje. Gjennom den prøver vi generelt å opprettholde en mental og kroppslig balanse, og samtidig utvikler vi vår sensitivitet. Samspillsdimensjonen omfatter handling, kommunikasjon og samarbeid. Gjennom den prøver vi generelt å oppnå en sosial og samfunnsmessig integrasjon som vi finner akseptabel, og samtidig utvikler vi vår sosialitet. Illeris sin grunnleggende tese er at all 
læring involverer disse to prosessene og tre dimensjonene, og at alle disse alltid må tas med i betraktningen hvis en forståelse eller analyse av en læringssituasjon eller et læringsforløp skal være utførlig.

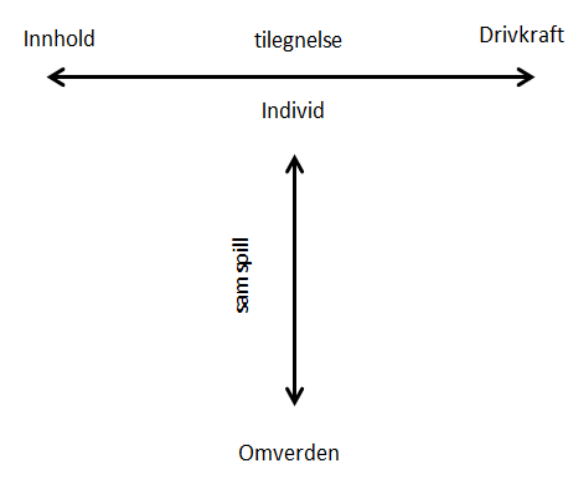

Figur 1: Læringens fundamentale prosesser (Illeris, 2012, s. 41).

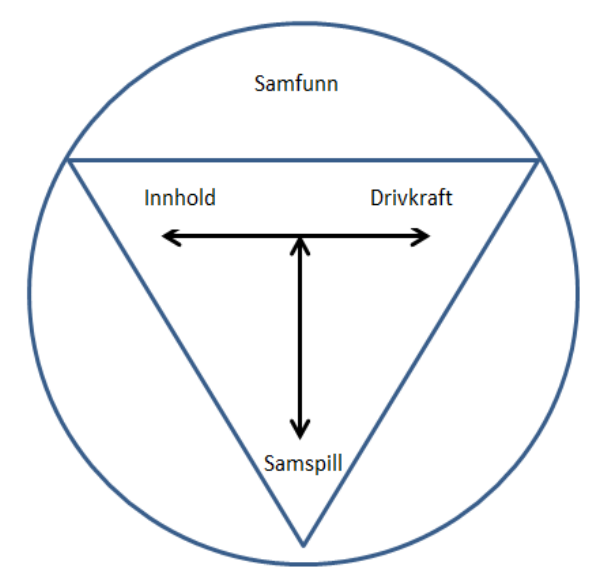

Figur 2: Læringens dimensjoner (Illeris, 2012, s. 43).

\section{Veiledning}

Definisjoner av veiledningsbegrepet er mange. Sentralt i forståelsen av begrepet står ofte både læringsaspektet og det relasjonelle aspektet. Fokuset er rettet mot den lærende og at veiledning inkluderer en form for samspill eller samarbeid (Tveiten, 2013). Ifølge Tveiten (2013, s. 21) defineres veiledningsbegrepet som «... en formell, relasjonell og pedagogisk istandsettingsprosess som har til hensikt at fokuspersonens mestringskompetanse styrkes gjennom dialog basert på kunnskap og humanistiske verdier». Istandsettingsprosessen har en start og en avslutning, og man skal selv være i stand til å gjøre det man har forutsetning til. Veiledningsansvaret er delt, der veilederen ansvarliggjøres med å legge til rette for istandsetting. Fokuspersonens ansvar blir å videreføre det som han eller hun er i stand til, for eksempel endringer. Dette er en formell virksomhet som går inn i et arbeidsforhold. Den rasjonelle delen henspeiler relasjonen mellom veileder og fokuspersonen, mens den pedagogiske istandsettingsprosessen inkluderer læring, vekst, utvikling og mestring. Videre mener Tveiten (2013) at dialog er hovedformen i veiledningen som baseres på humanistiske verdier og kunnskaper. 


\section{Lærernes tilbakemeldinger som en del av veiledningen}

Tilbakemeldinger er, ifølge Gamlem (2014), informasjon som blir gitt, mottatt eller søkt som handler om kvalitetsaspekt ved egen prestasjon eller forståelse. Formålet med en tilbakemelding er at informasjonen skal gi retning for videre arbeid og læring. De bør være av en karakter som gir studenten en opplevelse av meningsfull informasjon som kan brukes og blir brukt fordi den kan styrke deres forståelse, kunnskap og kompetanse gjennom lærling (Gamlem, 2015). Ifølge Hoel (2008) vil skriftlige tilbakemeldinger fra veileder til student inngå i en læringsprosess, der formålet er å føre studenten inn i en fagkultur og utvikling som fagperson. Dette innebærer at studenten får øving i kritisk sans og refleksjon. Lauvås og Handal (1998) har gjennom mange års arbeid med veiledning i høyere utdanning utarbeidet strategier for veiledning. Disse innbefatter å synligjøre det som er bra, å peke på det som er verneverdig i teksten, å klargjøre det som er uklart, gi retning til det uferdige arbeidet og gi energi og lyst til å arbeide med det som gjenstår. I en studie fra 2013 er disse strategiene videreført og videreutviklet. Handal, Lycke og Lauvås (2013) oppsummerer veiledningsstrategier innenfor høyere utdanning i følgende kategorier: vurderende kommentarer (anerkjennende og kritiske), råd, metakommunikasjon, invitasjon til studenten om å ta del i dialogen og prosess- og produktveiledning.

\section{Metode}

\section{Metodologisk tilnærming}

Med bakgrunn i problemstillingen, som er knyttet til studenters opplevelse av undervisning og veiledning, har studien en fenomenologisk- hermeneutisk tilnærming. Fenomenologien har som formål å fokusere på beskrivelser av menneskers erfaringer, nærmere bestemt deres livsverden (Alvesson \& Sköldberg, 2008). Den tyske filosofen Edmund Husserl (1859-1938) regnes som den moderne fenomenologiens grunnlegger. Livsverdensbegrepet som Husserl utviklet er en betegnelse på den kunnskap som danner et nødvendig utgangspunkt for all forståelse, og som vi stort sett tar for gitt. Husserls ide var at forskeren skulle legge bort mest mulig av faktuelle teorier om verden, og gå Zu den Sachen selbst (Alvesson \& Sköldberg, 2008, s. 165). Dette kan forstås som å utforske vesenets egenart ved å skildre og forstå det som utforskes så nøytralt som mulig, uten annen påvirkning. 
Målet med hermeneutikken er å oppnå en gyldig forståelse av meningen i teksten.

Utgangspunktet er å forstå teksten, og at meningen hos en del kan forstås hvis den settes i sammenheng med helheten (Alvesson \& Sköldberg, 2008, s. 193). Sentralt begrep er den hermeneutiske sirkelen, der delen kan oppfattes ut i fra helheten og omvendt. Den hermeneutiske sirkelen har følgende grunnsteg: 1)Tolkningsmønsteret vokser frem fra særegenheter i teksten. Et mønster som bringer en dypere forståelse- refleksjon og forforståelse. 2) Tekst - plassere teksten i sin kontekst. Tolkningsmønsteret justeres via større innsikt- og hva som oppfattes som fakta. 3) Dialog- stiller spørsmål til teksten. Forforståelsen endres underveis. Veksler mellom gammel og ny forståelse. Er i dialog med leseren. 4) Deltolkninger skjer under hele prosessen sett ut fra visse bakgrunnsforestillinger (Alvesson \& Sköldberg, 2008, s. 194).

Ut i fra den nevnte metodologiske tilnærming har vi i analysearbeidet valgt Lindseth og Norbergs (2004) fenomenologiske-hermeneutiske fremgangsmåte basert på Giorgis (2009) trinnvise fortetning. Denne metoden bevarer meningen til den enkelte student, samtidig som den gir rom til tolking av tekstene (Lindseth \& Norberg, 2004).

Forskningsetiske prinsipper ble fulgt gjennom studien (Kvale, Brinkmann, Anderssen \& Rygge, 2015). Studentene ble informert før oppstart av studien, med informasjon om at det var frivillig å skrive logg og at de kunne trekke seg underveis. Forfatterne var begge involvert i både undervisning av skriveverkstedet og i tilbakemeldingene på oppgavene, noe som har metodisk utfordringer som vi har prøvd å være bevisst.

\section{Utvalg}

Deltagerne i denne studien er 12 førsteårsstudenter ved yrkesfaglærerutdanningen i Trondheim. Yrkesfaglærerutdanningen er samlingsbasert studium med tre samlinger hvert semester. Studentene har fagbakgrunn innenfor helse- og oppvekstfag. Eksempler på yrker er helsefagarbeider, barne- og ungdomsarbeider og hudpleier. Alle er kvinner med en aldersspredning fra 27 - 46 år. Gjennomsnittsalderen er 39 år. Studentene har mange års yrkeserfaring innenfor sin yrkeskompetanse/fagbrevområde. De ble rekruttert til studien gjennom å takke ja til studieplass høsten 2014. 


\section{Tiltakene}

Det første tiltaket, et todagers kurs med innføring i å skrive en akademisk oppgave, ble organisert på den første samlingen. Undervisningen var lagt opp som en veksling mellom å presentere teori om å skrive en slik oppgave og praktiske øvelser. Vi startet med en gjennomgang av kjennetegn ved akademiske skriving som beskrevet innledningsvis (Busch, 2013). Deretter hadde vi en gjennomgang av IMRoD- struktur (Hoel, 2008). Mellom presentasjonene hadde vi lagt inn tid til praktiske øvelser. På dag to ble det presentert en klargjøring av hva som ligger i ulike begrep som ofte brukes i oppgavetekster (eksempelvis beskriv, nevn, drøft) samt en gjennomgang av krav til litteraturlister i akademiske tekster og hvordan kildene refereres til i flytende tekst (VIKO, 2014). Ved kursets slutt hadde studentene utarbeidet en skisse til en akademisk oppgave med forside, innholdsfortegnelse, innledning med en egenformulert problemstilling, hoveddel, avslutning og litteraturliste.

Det andre tiltaket var ulike og varierte former for tilbakemeldinger på oppgaver. Alle studenter fikk skriftlige tilbakemeldinger på fem oppgave det første semesteret (to i gruppe, tre individuelle). I tillegg fikk de en muntlig tilbakemelding (30 minutter per student) hvor de selv kunne bestemme hva som skulle være i fokus. Den muntlige tilbakemeldingen ble gitt mens studentene var på sin tredje og siste samling i første semester. Noen studenter fikk også digitale tilbakemeldinger. De digitale tilbakemeldingene ble gitt ved hjelp av en skjermvideo produsert ved hjelp av programvarer Screencast-O-Matic hvor lærerne ga muntlige tilbakemeldinger til studentene, samtidig med at studentenes oppgaver ble synlig $\mathrm{i}$ skjermbildet. Videoene hadde en varighet på ca. 15 minutter, og ble sendt tilbake til studentene sammen med den skriftlige tilbakemeldingen på læringsplattformen It’s learning. De digitale tilbakemeldingene ble gitt på en gruppeoppgave og en individuell oppgave. Studentene fikk beskjed om å lese den skriftlige tilbakemeldingen før de så videoen.

De tre formene for tilbakemelding er i utgangspunktet gitt på de samme språklige og tekstlige forhold slik at de i hovedsak har samme innhold. De skriftlige tilbakemeldingene danner dermed utgangspunktet for de muntlige og digitale. Vi vil med utgangspunkt i teori om tilbakemelding (Lauvås \& Handal, 1998; Handal, Lycke \& Lauvås, 2013) gi eksempler på konkrete tilbakemeldinger som ble gitt i de skriftlige oppgavene. Eksempel på en tilbakemelding på det som er bra er kommentarer som «Ryddig innholdsfortegnelse». Eksempel på en verneverdig tilbakemelding i teksten er «Casen du har laget gir en god beskrivelse av situasjonen og er et godt utgangspunkt for drøfting». Eksempel på klargjørende 
tilbakemelding er «Mye bra! Hvis du skal få til mer drøfting kan du prøve å se saken fra et annet synspunkt. Hva hadde skjedd hvis hjelpepleieren ikke var så imøtekommende?» Eksempel på tilbakemeldinger som gir retning til det uferdige arbeidet er «Se nærmere på strukturen- alle oppgaver skal ha en innledning, hoveddel og avslutning». Eksempel på tilbakemeldinger som gir lyst og energi til å arbeide med det som gjenstår er «Du er på rett vei, stor forbedring fra sist!» Til sist kommer et eksempel på en tilbakemelding på invitasjon til studenten om å ta del i dialogen og prosessen: «Fint at du peker på læreren som rollemodell. Hvordan kan læreren som rollemodell bidra til relasjonsbygging mellom lærer-elev?» Etter at vi har gitt kommentarer direkte i teksten, avslutter vi med en kort oppsummerende tekst der vi trekker ut noen essenser.

\section{Datainnsamling}

Dataene i studien er samlet inn gjennom to refleksjonslogger. Studentene skulle svare på spørsmål om deres opplevelser av innføringskurset og de ulike formene for tilbakemeldinger som ble gitt. I den første loggen ble blant annet følgende spørsmål stilt: Hvilke opplevelser har du av skrivekurset? I den andre refleksjonsloggen ble følgende spørsmål stilt: 1) Kan du beskrive dine opplevelser med å få skriftlig tilbakemelding på ulike oppgave? 2) Kan du beskrive dine opplevelser med å få muntlig tilbakemelding? 3) Kan du beskrive dine opplevelser med å få digital tilbakemelding? Studentene leverte refleksjonsloggene på It's learning etter første og tredje samling. Alle 12 bevarte samtlige spørsmål på begge loggene (til sammen 24 logger).

\section{Analyse}

Analysearbeidet er som tidligere nevnt basert på Lindseth og Norbergs fenomenologiskehermeneutiske fremgangsmåte (2004). De anvender formuleringer i et fenomenologisk språk ved utforming av temaene. Bruk av verb blir benyttet i stedet for substantiver, for eksempel: Å få bekreftende tilbakemelding. Fremgangsmåten beskrives i 3 faser: 1) Naiv lesning. Vi leste gjennom loggene flere ganger for å kunne forstå meningen som en helhet. Dette er den første antagelsen om meningen i teksten, derfor må den valideres i den påfølgende analysen. 2) Strukturell analyse er i dette tilfelle en tematisk strukturell analyse som innebærer at en leser hele teksten, deretter deles teksten i flere meningsenheter, det vil si utdrag fra teksten. Deretter ble teksten delte opp i meningsenheter - deler av en setning. Meningsenhetene ble fortettet og skrevet om til dagligspråk med korte formuleringer (sammentrekning). Deretter blir teksten delt opp i undertema og tema. 3) Helhetlig forståelse. I den siste fasen blir 
undertema og tema reflektert over og satt i sammenheng med problemstillingen, samtidig som teksten ble lest gjennom som en helhet med en naiv forståelse. Et eksempel på denne kodingen presenteres i tabellen nedenfor.

\begin{tabular}{|l|l|l|l|}
\hline \multicolumn{1}{|c|}{ Meningsenhet } & \multicolumn{1}{|c|}{ Sammentrekning } & \multicolumn{1}{|c|}{ Undertema } & \multicolumn{1}{|c|}{ Tema } \\
\hline $\begin{array}{l}\text { Noe av det jeg skriver føler jeg blir bra ... } \\
\text { mens andre ting jeg skriver kan jeg bli litt } \\
\text { usikker på om jeg er inne på noe eller helt } \\
\text { på villspor. Derfor syns jeg det er } \\
\text { kjempeviktig med skriftlig tilbakemelding. }\end{array}$ & bra, men blir også usikker & $\AA$ føle på usikkerhet & $\AA$ få bekreftende \\
tilbakemelding
\end{tabular}

Tabell 1: Eksempel på koding av data.

\section{Resultater og diskusjon}

Akademisk skriving er et nytt landskap å bevege seg inn i for mange yrkesfaglærerstudenter.

De skal ikke bare uttrykke seg på en relevant måte, de skal også forholde seg til klare retningslinjer for innhold, struktur og referansesystemer som er sentrale spilleregler når de skal besvare oppgaver i studiet. For å veilede og støtte studentene i læringsprosessen av disse spillereglene har vi i tillegg til å undervise i akademisk skriving tatt i bruk ulike former for tilbakemelding på oppgaver. Ifølge Boge, Markhus, Moe og Ødegaard (2002) innebærer veiledning i profesjonsutdanningene både undervisning og studieveiledning. Med utgangspunkt i skrivekurset og de ulike formene for tilbakemelding vil vi i det følgende diskutere temaene som kom til syne gjennom analysen av studentenes refleksjonslogger. I tillegg har vi valgt å avslutte med noen betraktninger om skriving av refleksjonslogger i lærerutdanning. 


\section{Innføringskurs i akademisk skriving}

Et innføringskurs i akademisk skriving med presentasjon av teori, forklaringer og praktiske $\varnothing$ vinger var det første tiltaket vi iverksatte. To av temaene som stiger fram av analysen er at skrivekurset ble opplevd som nyttig og at samarbeid med medstudenter var av stor betydning for læringsutbytte. Alle studentene gir på ulike vis uttrykk for at de har hatt stort utbytte av å delta i undervisningen, og mange gir uttrykk for at de ikke har noe kjennskap til akademisk skriving fra før. En student skriver: «....jeg visste ikke noe om hvordan en oppgave skal skrives». Andre sier: «Nå har jeg en mye større forståelse av hvordan en oppgave skal bygges opp og hva den skal inneholde». Noen konkretiserer hva som var nyttig. Eksempler på dette er: «Jeg fikk en del informasjon om hvordan innhold og oppsett skal være» og «Kjempebra at vi studenter fikk øve på å problemformulere, samt å komme litt i gang med en oppgave som $\emptyset$ ving». «Skrivekurset var et «must» for min del!» er det en student som oppsummerer. Illeris (2012) hevder at all læring involverer både tilegnelse- og samspillsprosesser. Det faglige innholdet i presentasjonene fra skrivekurset favner innholdsdimensjonen mens de praktiske $\emptyset$ velsene favner samspillsdimensjonen. For oss ble det veldig tydelig at samspillet mellom studentene i de praktiske $\emptyset$ velsene og samspillet med oss som lærerne i undervisningen hadde stor betydning for læringsutbytte og opplevelse av kursets nytteverdi i sin helhet. Opplevelse av nyttig innhold og godt samspill er en viktig drivkraft i læreprosessen og bidrar til vilje og motivasjon til å fortsette skrivearbeidet ifølge Illeris (2012). Vi opplever at studentenes logger gjenspeiler dette samtidig som vi ser tydelig at akademisk skriving kan virke vanskelig og skremmende i starten av et universitetsstudium. Vi fikk også erfare at dårlig samspill kan ha motsatt effekt. En student skriver: «For min del ble samarbeidet med medstudent lite vellykket, som førte til at jeg ble sittende igjen med lite utbytte av dagen». Opplevelsen av mislykket samarbeid kan svekke motivasjonen og viljen til videre innsats.

Rienecker og Jørgensen (2006) peker på at å lære akademisk skriving og å lære fag støtter hverandre gjensidig. Dette innebærer at arbeid med skriving i fagene i lærerutdanningen ikke nødvendigvis går på bekostning av opplæring i andre fag. Den samme forståelsen finner vi i Kunnskapssløftet der ideen om skriving i alle fag skal styrke både skrivekompetanse og læring i de ulike fagene. Hoel (2008) understreker at det er viktig at studentene får en innføring i akademisk skriving på et tidlig tidspunkt i studiet, slik at de får en fast ramme å forholde seg til. Hun gir to konkrete råd til nye studenter. Det ene handler om å skape en god struktur med overordnede og underordnede nivå i teksten. Det andre er å være pinlig nøyaktig med referanser, sitat og litteraturliste. Å mestre dette håndverket gir trygghet, skriver hun. 
Tiltak som fremmer trygghet er noe førsteårsstudenter i yrkesfag sårt trenger, noe vi vil komme tilbake til.

\section{Ulike former for tilbakemelding}

Det andre tiltaket vi iverksatte var skriftlige, muntlige og digitale tilbakemeldinger på oppgaver. Følgende temaer kom til syne basert på spørsmål om hvordan studentene opplevde å få ulike former for tilbakemelding: Å få bekreftende tilbakemelding, Å få oppklarende tilbakemelding, Å få motiverende tilbakemelding og A ha relasjon $i$ veiledning. Resultatene knyttet til de skriftlige tilbakemeldingene presenteres først, deretter resultatene knyttet til de muntlige og digitale tilbakemeldingene.

\section{Skriftlige tilbakemeldinger}

Helt siden studiets oppstart har studentene fått skriftlige tilbakemeldinger. Studentene opplever at skriftlige tilbakemeldinger viser vei i det videre skrivearbeidet. En student skriver at det er godt å få høre hva som kan forandres i oppgaven for å kunne gjøre den bedre, og at tilbakemeldinger gjør at man vet hva man kan arbeide videre med. Å få kommentarer direkte i teksten oppleves som konkret og nyttig. Konkrete kommentarer gjør det lettere når oppgaven skal videreutvikles. Likeså peker studentene på at «Fine og oppløftende avslutninger gir motivasjon og mening». Studentene beskriver her det som skjer i møtet mellom læringsinnhold, drivkraft og omverden illustrert i Figur 1 og 2 (Illeris, 2012). Skriftlige tilbakemeldinger i teksten gir mening og sammen med motivasjon for læring tilegner studenten seg nye kunnskaper og ferdigheter i skrivearbeidet. Læringen skjer i individet, men foregår i et samspill med læreren som har gitt disse kommentarene.

Selve innholdet i kommentarene er av stor betydning. Flere studenter peker på hvor viktig det er å få ros. En student sier: «Det er fint å få tilbakemelding på det som er bra. Det gjør noe med selvfølelsen og gjør at man har lyst til å fortsette med skriveprosessen». En annen student skriver at det er viktig med kommentarer som viser hva som er bra, men også kommentarer på hva som det ikke trengs å gjøres noe med. Slike kommentarer virker også som bekreftelse på at en er på riktig vei. En student skriver: «Noe av det jeg skriver føler jeg blir bra, mens andre ting jeg skriver kan jeg bli litt usikker på om jeg er inne på noe, eller helt på villspor». Hun 
skriver videre at skriftlige tilbakemeldinger derfor er svært viktig. Hun opplever at lærerens kommentarer bekrefter eller avkrefter om hun er på riktig vei. Det virker som at kommentarbobler underveis i teksten som roser, oppklarer og bekrefter, med klare instrukser om hva som er bra og hva som kan videreutvikles oppleves som nyttig. Dette er i samsvar med andre veiledningsstudier (Gamlem, 2015; Hoel, 2008; Lauvås \& Handal, 1998).

Studentene peker også på ulike utfordringer knyttet til skriftlige tilbakemeldinger. Flere studenter skriver at det er ikke alltid de forstår hva tilbakemeldingene betyr eller hvordan de skal tolke dem. Etter hvert som studentene får flere tilbakemeldinger blir dette lettere. En students skriver: «Etter å ha sammenlignet den skriftlige tilbakemeldingen på begge individuelle oppgave skjønner jeg bedre budskapet i dem, samt at jeg begynner å forstå ordlyden i lærerens språk». Som veiledere er det viktig å være å være klar over at kommentarer kan oppfattes og tolkes ulikt av studentene. Hvor godt student og lærer kjenner hverandre og hvor studenten er i sin læringskurve har betydning både for hvordan tilbakemeldinger blir tatt imot og hvordan innholdet i dem blir forstått. Det er derfor viktig å bli kjent med studentene slik at læreren kan tilpasse antallet kommentarer, balansen mellom utviklingskommentarer og ros og ikke minst innholdet i responsen til den enkelte student. I følge både Illeris (2012) og Tveiten (2013) er relasjonen mellom veileder og student helt sentral for læring, vekst, utvikling og mestring.

Videre er det viktig at studentene arbeider aktivt med tilbakemeldingene slik at de trener seg opp til å tolke veiledningskommentarer. En student viser dette når hun skriver at etter flere tilbakemeldinger skjønner hun bedre lærerens «språk» og «budskap». Ifølge Tveiten (2013) er ansvaret i veiledningen delt. Veilederen har blant annet ansvar for å legge til rette for at studenten skal ha mulighet til å videreføre det som hun eller han er i stand til. Studenten har ansvar for å gjøre endringer knyttet til veilederes kommentarer som oppfattes som meningsfulle.

Andre utfordringer knyttet til skriftlige tilbakemeldinger er omfanget av kommentarer. En student forteller at det oppleves som vanskelig å utvikle seg hvis det er få tilbakemeldinger. Vedkommende foretrekker heller mange og negative tilbakemeldinger enn få og bare positive. Noen studenter er dermed mer opptatt av utviklingskommentarer enn mengde ros, mens andre mister motivasjonen om tilbakemeldingen ikke inneholder tilstrekkelig med ros. En student skriver: «Uansett hvor dårlig oppgaven var følte jeg det burde kommet fram noe som motiverte meg for videre arbeid (...) men motivasjonen forsvant med tilbakemeldingen». 
Med få og uklare kommentarer i tilbakemeldingen er det vanskelig å vite hva en skal jobbe videre med. Er det derimot mange kommentarer, kan det også virke demotiverende. Antallet kommentarer må derfor sees i sammenheng med hva som står i dem. Noen studenter utrykker klart at de fortrekker mange kommentarer som kan gjøre oppgaven bedre fremfor påpekning om hva som er bra, andre sier de mister motivasjonen dersom det er mange kommentarer som peker på hva som kan utvikle teksten videre og få kommentarer med ros.

En del studenter gir uttrykk for stor usikkerhet og sårbarhet. De bruker uttrykk som «redd for å være på villspor». Noen ber også om skriftlige kommentarer som bekrefter hvilke deler av teksten som er bra og hvilke deler som ikke krever endringer. For noen er det ikke tilstrekkelig at deler av teksten står urørt, det må en konkret bekreftelse til for at de skal være sikre på at innholdet holder mål. Andre studenter etterspør tilbakemeldinger på hvor de ligger i nivå slik at de vet at oppgaven holder til en ståkarakter. I starten av et nytt studium er det derfor svært viktig med mye bekreftelse og ros. Studenter skriver at selv om den innleverte teksten er mangelfull, så oppleves ros som motivasjon til å videreutvikle oppgavene. Ros fremmer studentenes motivasjon, mestring og selvfølelse. Dette samsvarer med Lauvås og Handal (1998) som understreker viktigheten av å løfte opp det som er bra i en tekst. Å utvikle skriveferdigheter tar tid. Når en blir bedre kjent med den enkelte, kan en som veileder utfordre mer. Å trygge studentene i starten av et studium er derfor en viktig del av veiledningsarbeidet (Lauvås, Hofgaard \& Handal, 2013). Gamlem (2014) peker på viktigheten av emosjonell støtte. I sitt doktorgradsarbeid skriver hun at emosjonell støtte er sentralt for å skape trygghet og et positivt læringsmiljø. Hun skriver videre at det er behov for å styrke både lærere og elever sin kompetanse på tilbakemelding og samhandling som støtte for læring.

\section{Muntlige tilbakemeldinger}

Muntlige tilbakemeldinger på oppgavene ble gitt mens studentene var på sin siste samling i første semester. De skriftlige tilbakemeldingene tidligere i semesteret dannet utgangspunktet for de muntlige. På spørsmål om hvilke opplevelser studentene har av muntlige tilbakemeldinger, kommer det tydelig fram at også denne formen for veiledning er viktig for den videre skriveprosessen. Studentene løfter spesielt frem at misforståelser i de skriftlige tilbakemeldingene ofte ble oppklart gjennom dialog med læreren. En av studentene meddeler: «Muntlig tilbakemelding syns jeg var bra å få fordi noe av den skriftlige tilbakemeldingen kan jeg bli usikker på. Litt usikker på om jeg forstod helt hva lærerne mente». Videre kommenterer en annen student: «Det er enklere å spørre om råd og forstå hva som menes med 
de ulike kommentarene ved å snakke sammen». Studenten som forteller om motivasjonen som forsvant med den skriftlige tilbakemeldingen, svarer slik på spørsmålet om opplevelser med muntlige tilbakemeldinger: «I etterkant av denne samtalen følte jeg meg motivert for å jobbe mer med oppgaven og ser absolutt ikke mørkt på å sette i gang med framtidig oppgaver».

Utsagnene over illustrerer at studentene opplever at dialog og personlig møte med læreren er viktig. En student skriver: «... fint å snakke med læreren innimellom». En annen student uttrykker: «Det å snakke i telefonen for å få oppklaring på punkter i oppgave er ikke det samme som å sitte i samme rom». Muntlige tilbakemeldinger bidrar til å bygge relasjoner mellom lærer og student i tillegg til at denne formen for tilbakemelding oppleves både oppklarende, bekreftende og motiverende.

Studien tyder på at studentene har behov for muntlige tilbakemeldinger i tillegg til de skriftlige. Å ha mulighet for å snakke med læreren innimellom beskrives av flere studentene som en fordel. De opplever da å ha mulighet å stille spørsmål og oppklare det som de ikke forstod i de skriftlige tilbakemeldingene. Muntlig tilbakemelding etter en skriftlig ser derfor ut til å være hensiktsmessig. Illeris (2012) fremhever også betydningen av samspillsdimensjonen i sine modeller for læring. Lærer og student inngår i en felles handling om oppgaven der kommunikasjon og samarbeid er viktige prosesser for videre utvikling i skrivearbeidet.

\section{Digitale tilbakemeldinger}

Digitale tilbakemeldinger ble gitt ved at studentene fikk se oppgaven med lærerens kommentarer i skjermbildet samtidig som læreren snakket om innholdet i de skriftlige kommentarene. En student skriver dette:

Jeg skjønte responsen bedre når jeg leser selv og får det som film. Føler bedre at jeg «fikk kontakt» og var mer konsentrert enn når jeg bare får skriftlig respons på ark. Jeg satt igjen med et mer positivt bilde på oppgaven enn hvis det bare var skrevet.

Det er tydelig at å lytte til hva som blir sagt og se kroppsspråket til læreren påvirker hvordan innholdet i kommentarene oppleves og blir mottatt. Tilbakemeldinger gitt på denne måten virker ifølge studentene positivt inn på hvordan kommentarene forstås. En annen student skriver: «Det er nesten som å ha veilederen hos meg gjennom veiledningen, og det er en stor fordel for meg». Flere utsagn tyder også på at digitale tilbakemeldinger gir studentene en 
følelse av at læreren bryr seg om dem. En student uttrykker dette slik: «Følte at læreren bryr seg mer og får kontakt med oss studenter med å «gidde» å sette seg fremfor et kamera å fortelle».

En annen side ved digitale tilbakemeldinger som ble synlig i studentenes logger, er muligheten til å se og høre tilbakemeldingen flere ganger. En student forteller at hun i arbeidet med oppgaven videre så videoen flere ganger. Hun skriver: «Det er lettere å gå tilbake og gjøre endringer i oppgaven når en får slike tilbakemeldinger (...)». Studentene som fikk digitale tilbakemeldinger var entydig positive og svært begeistret for denne formen for veiledning. De opplever at lærerne bryr seg mer om deres faglige utvikling når det settes av tid til muntlig og digital tilbakemelding. Det er liten tvil om at de muntlige og digitale tilbakemeldingene supplerer de skriftlige på måter som oppleves som viktige og positive. Dessuten kan studentene gjennom det digitale mediet danne seg et annet bilde av oppgaven. Flere studenter forteller om at de sitter igjen med et mer positivt bilde av oppgaven etter muntlig og digital respons.

Studentene har ikke pekt på utfordringer knyttet til muntlige og digitale tilbakemeldinger, men som lærerutdannere på et samlingsbasert studium bør disse nevnes. En av utfordringene knyttet til å gi flere former for tilbakemelding på de samme oppgavene er bruken av tid. Det må settes av tid til muntlig tilbakemelding til hver enkelt student på tidspunkt som ikke hindrer fellesundervisningen. Dette krever god timeplanlegging. Å produsere digitale responser på 15 minutter, slik vi gjorde i denne studien, tar gjerne en halv time ekstra når skriftlige kommentarer er utarbeidet i forkant av skjermopptakene. Denne formen for tilbakemelding forutsetter at læreren er villig til å lage digitale tilbakemeldinger samt å dele videoen med andre. Vår erfaring er at dette er vel anvendt tid på denne type studium. Studentenes opplevelser av skrivekurset og ulike former for tilbakemelding viser at yrkesfaglærerstudenter har et stort behov for tett oppfølging og mye støtte i læringsprosessen med å videreutvikle sine skriveferdigheter.

\section{Skriving av refleksjonslogger i lærerutdanningen}

Dataene i denne studien ble samlet inn gjennom refleksjonslogger. I loggskriving fanger man opp studentenes egne erfaringer, forståelse og oppfatninger ut fra gitte spørsmål. Illeris (2012) peker på at refleksjon er tett knyttet til læring. Sammen med skrivekurset og ulike former for 
tilbakemelding kan regelmessig skriving av refleksjonslogger i lærerutdanningen være et godt hjelpemiddel for å styrke studentenes skriveferdigheter. Illeris (2012) peker på at begrepet refleksjon dreier seg både om ettertanke og om speiling. Ved ettertanke reflekterer man nærmere over noe, mens man ved speiling speiler sin opplevelse eller forståelse av noe i sitt eget selv eller i en annens reaksjon. I forhold til opplæring i akademiske skriving vil vi si at studentene konsentrerer seg om betydningen som undervisning og lærernes tilbakemeldinger har hatt for dem, vurderer dem med sin egen identitet som målestokk. Loggene i denne studien har gitt studentene viktig skrivetrening, og oss lærere viktig informasjon om studentenes behov og tanker om egen skrivekompetanse. Ifølge Eik-Nes (2008) kan loggskriving være et unikt verktøy for å bearbeide usikkerhet når de skal utforme egen rolle som student. Studenter har ulike læreforutsetninger og dermed ulike behov for støtte i skriveprosessen. Logger kan være et multiverktøy som kan fylle ulike behov for de forskjellige lærerstudenter (Klemp, 2012).

Hoel (2002) peker på loggskriving som en viktig mediator for læring knyttet til respons som et nødvendig aktiviserende prinsipp. Gjennom loggskriving og responsarbeid kan lærerutdannere støtte og utfordre lærerstudenter i refleksjonsarbeidet. Gjennom regelmessige refleksjonslogger om ulike temaer i studiet kan opplæring i akademisk skriving og fag støtte hverandre gjensidig, slik Rienecker og Jørgensen (2006) peker på.

\section{Oppsummering}

Hensikten med denne studien er å utforske hvordan et innføringskurs i skriving av akademiske oppgaver og ulike former for tilbakemelding oppleves av førsteårsstudentene i yrkesfaglærerutdanningen. Resultat i studien tyder på at studentene opplever at et innføringskurs i akademisk skriving er nødvendig for den videre skriveprosessen. De fleste studentene har liten eller ingen erfaring med oppgaveskriving i høyere utdanning. I tillegg er det relasjonelle aspektet i veiledning sentralt. Ros, støtte og personlig kontakten med lærer fremheves som avgjørende for motivasjon til videre arbeid. Dette er aspekter som på ulike måter er knyttet til både skriftlige, muntlige og digitale tilbakemeldinger. De ulike formene for tilbakemeldinger har sine styrker og sine utfordringer. Skriftlig tilbakemeldinger oppleves som et «must» i lærerutdanningen, kommentarbobler underveis i teksten sammen med en oppsummerende tekst til slutt er en form for skriftlig tilbakemelding studentene opplever som 
konkret, oppklarende, bekreftende, meningsfull og motiverende. Muntlige tilbakemeldinger har sin styrke i at de oppleves som oppklarende og at dialog med lærer styrker betydningen av de skriftlige tilbakemeldingene. Muligheten til å kunne se og lytte til tilbakemeldingene flere ganger trekkes frem som spesielt gunstig i forhold til de digitale. Resultatene underbygger viktigheten av variert veiledning i arbeidet med å kvalifisere yrkesfaglærerstudenter i akademiske skriveferdigheter. Funnene i denne studien samsvarer godt med Illeris (2012) sin læringsteori der både innhold-, drivkraft- og samspillsdimensjonen gjennom tilegnelses- og samspillsprosesser er involvert i studentenes læringsprosesser. Studentene gir uttrykk for at tilbakemeldinger gir liten læringseffekt hvis veilederen ikke tar hensyn til disse aspektene og kompleksiteten i læringsprosessen.

Det er lærerinstitusjonene sitt ansvar å legge til rette for at studentene får tilstrekkelig kunnskap, Øving og oppfølging i skrivearbeidet. I Forskrift om rammeplan for den treårige yrkesfaglærerutdanningen står det at studiet skal kvalifisere studenter til å kunne gi læringsfokuserte tilbakemeldinger, og de skal arbeide systematisk med grunnleggende ferdigheter (Kunnskapsdepartementet, 2013). Hellne-Halvorsen (2014) sin doktoravhandling om skrivepraksiser på yrkesfaglige utdanningsprogrammer viser at yrkesfaglærere trenger sammensatte skrivekompetanser. Det er derfor svært viktig at fremtidige yrkesfaglærere får opplæring og trening med ulike skrivekompetanser i løpet av lærerstudiet slik at de kan arbeide systematisk med grunnleggende ferdigheter og tilbakemeldinger i egen undervisning. Vi ser det som nødvendig at skriving får mer plass i yrkesfaglærerutdanningen, både for å holde tritt med de $\varnothing$ vrige lærerutdanningene og for at studentene skal stå godt rustet til videre studier og en fremtidig lærerjobb. 


\section{Referanser}

Alvesson, M. \& Sköldberg, K. (2008). Tolkning och reflektion: Vetenskapsfilosofi och kvalitativ metod. Lund: Studentlitteratur.

Boge, M., Markus, G., Moe, R. \& Ødegaard, E. E. (2002). Laering gjennom veiledning: Meningsskaping i grupper (2.utg.). Bergen: Fagbokforlaget.

Busch, T. (2013). Akademisk skriving for bachelor- og masterstudenter. Bergen: Fagbokforlaget.

Eik-Nes, N. L. (2008). Dialogging: Negotiating Disciplinarty Identity through the Medium of Logs. (Doktorgradsavhandling), NTNU, Trondheim.

Firing, K., Klomsten, A. T. \& Moen, F. (2013). Masterstudenters opplevelser av møter med veileder: Det er veiledning som gjør at en føler en mestrer. Uniped, 36(2), 81-92.

Gamlem, S. M. (2014). Tilbakemeldinger som stфtte for laering på ungdomssteget. (Doktorgradsavhandling), Universitetet i Stavanger, Stavanger.

Gamlem, S. M. (2015). Tilbakemelding for laering og utvikling. Oslo: Gyldendal akademisk.

Giorgi, A. (2009). The descriptive phenomenological method in psychology: A modified husserlian approach. Pittsburg: Duquesne University Press.

Grepperud, G., Rønning, W. M. \& Støkken, A. M. (2006). Studier og hverdagsliv: Voksne studenter i fleksibel laring. Trondheim/ Oslo: VOX.

Handal. G., Lycke, K. H., \& Lauvås, P. (2013). Strategier i forskningsveiledning?: En analyse av veilederes tilbakemelding på tekst. Uniped, 36(4), 32-44.

Handal, G. \& Lauvås, P. (2013). Forskningsveilederen (3. utg.). Oslo: Cappelen akademisk.

Hellne-Halvorsen, E. B. (2014). Skrivepraksiser i yrkesfaglige utdanningsprogrammer. (Doktorgradsavhandling), Universitetet i Oslo, Oslo.

Hoel, T. L. (2002). Interaction and learning potential in e-mail messages. I E. Maagerø \& B. Simonsen (Red.), Learning through genres (s. 15-38). Kristiansand: Høyskoleforlaget.

Hoel, T. L. (2008). Skriving ved universitet og høgskolar-for larerar og studentar. Oslo: Universitetsforlaget.

Hoel, T. L. \& Rokkones, K. E. (2012). Frå tommestokk til pc: Yrkesfaglærarstudentar og skriving. I S. Matre, S. Kibsgaard Sjøhelle \& R. Solheim (Red.), Teorier om tekst $i$ møte med skolens lese- og skrivepraksiser, s. 239-249. Oslo: Universitetsforlaget.

Illeris, K. (2012). Laring. Oslo: Gyldendal akademisk.

Klemp, T. (2012). Praksisloggen som multiverktøy: Hva bruker lærerstudentene den til? I S. Matre \& G. Melby (Red.), Å skrive seg inn i laereryrket, s. 89-112. Trondheim: Akademika.

Kunnskapsdepartementet (2013). Forskrift om rammeplan for yrkesfaglaererutdanning for trinn 8-13. Hentet den 03.06.2015 fra 
https://www.regjeringen.no/globalassets/upload/kd/vedlegg/rammeplanen/yrkesfaglaer erutdanning.pdf

Kvale, S, Brinkmann, S., Anderssen, T. M. \& Rygge, J. (2015). Det kvalitative forskningsintervju (3. utg., 2. opplag). Oslo: Gyldendal akademisk.

Lauvås, P. \& Handal, G. (1998). Hovedfagveiledning ved Universitet i Oslo: Rapport frå prosjektet «Vitenskapelig veiledning» (rapport 1/1988). Oslo: Universitetet i Oslo.

Lindseth, A. \& Norberg, A. (2004). A phenomenological method for researching lived experience. Scandinavian Journal of Caring Science, 18(2), 145-153.

Rienecker, L. \& Jørgensen, P. S. (2006). Den gode oppgaven: Håndbok i oppgaveskriving på universitet og høyskole. Bergen: Fagbokforlaget.

Tveiten, S. (2013). Veiledning: Mer enn ord (4. utg.). Bergen: Fagbokforlaget.

Utdanningsdirektoratet (2006). Kunnskapslфftet. Hentet den 25.09.2014 fra http://www.udir.no/Lareplaner/Kunnskapsloftet/

VIKO (2014). VIKO gir hjelp til litteraturs $\phi k$ og oppgaveskriving. Hentet den 25.09.2014 fra http://www.ntnu.no/viko/ 